\title{
Endothelial dysfunction in a murine model of mild hyperhomocyst(e)inemia
}

\author{
Robert T. Eberhardt, ${ }^{1,2}$ Marc A. Forgione, ${ }^{1,2}$ Andre Cap, ${ }^{1,2}$ Jane A. Leopold, ${ }^{1,2}$ \\ M. Audrey Rudd, ${ }^{1,2}$ Maria Trolliet, ${ }^{1,2}$ Stanley Heydrick, ${ }^{1,2}$ Rachel Stark, ${ }^{1}$ \\ Elizabeth S. Klings, ${ }^{1,3}$ Nicanor I. Moldovan, ${ }^{4}$ Mohammed Yaghoubi, ${ }^{1,2}$ \\ Pascal J. Goldschmidt-Clermont, ${ }^{4}$ Harrison W. Farber, ${ }^{1,3}$ \\ Richard Cohen, ${ }^{1,2}$ and Joseph Loscalzo ${ }^{1,2}$
}

${ }^{1}$ Evans Department of Medicine,

${ }^{2}$ Whitaker Cardiovascular Institute, and

${ }^{3}$ Pulmonary Center, Boston University School of Medicine, Boston, Massachusetts, USA

${ }^{4}$ Cardiology Division, Department of Medicine, The Ohio State University, Columbus, Ohio, USA

Address correspondence to: Joseph Loscalzo, Boston University School of Medicine, 715 Albany Street, W507, Boston, Massachusetts 02118, USA. Phone: (617) 638-4890; Fax: (617) 638-4066; E-mail: jloscalz@bu.edu.

Robert T. Eberhardt and Marc A. Forgione contributed equally to this work.

The results reported here were presented in part at the Experimental Biology '99 meeting in Washington, DC, USA, in April 1999.

Received for publication September 3, 1999, and accepted in revised form July 18, 2000.

\begin{abstract}
Homocysteine is a risk factor for the development of atherosclerosis and its thrombotic complications. We have employed an animal model to explore the hypothesis that an increase in reactive oxygen species and a subsequent loss of nitric oxide bioactivity contribute to endothelial dysfunction in mild hyperhomocysteinemia. We examined endothelial function and in vivo oxidant burden in mice heterozygous for a deletion in the cystathionine $\beta$-synthase (CBS) gene, by studying isolated, precontracted aortic rings and mesenteric arterioles in situ. $\mathrm{CBS}^{-/+}$mice demonstrated impaired acetylcholine-induced aortic relaxation and a paradoxical vasoconstriction of mesenteric microvessels in response to superfusion of methacholine and bradykinin. Cyclic GMP accumulation following acetylcholine treatment was also impaired in isolated aortic segments from $\mathrm{CBS}^{-/+}$mice, but aortic relaxation and mesenteric arteriolar dilation in response to sodium nitroprusside were similar to wild-type. Plasma levels of 8-epi-PGF $2 \alpha(8-I P)$ were somewhat increased in $\mathrm{CBS}^{-/+}$mice, but liver levels of 8-IP and phospholipid hydroperoxides, another marker of oxidative stress, were normal. Aortic tissue from $\mathrm{CBS}^{-/+}$mice also demonstrated greater superoxide production and greater immunostaining for 3-nitrotyrosine, particularly on the endothelial surface. Importantly, endothelial dysfunction appears early in $\mathrm{CBS}^{-/+}$mice in the absence of structural arterial abnormalities. Hence, mild hyperhomocysteinemia due to reduced CBS expression impairs endothelium-dependent vasodilation, likely due to impaired nitric oxide bioactivity, and increased oxidative stress apparently contributes to inactivating nitric oxide in chronic, mild hyperhomocysteinemia.
\end{abstract}

J. Clin. Invest. 106:483-491 (2000).

\section{Introduction}

Mild hyperhomocyst(e)inemia, a condition that can include elevated serum levels of homocysteine, homocystine, or homocysteine-mixed disulfides, is a risk factor for atherosclerosis and its thrombotic complications. Epidemiological studies have shown that even mild elevations of plasma homocyst(e)ine are associated with an increased risk of atherosclerosis, including peripheral arterial occlusive disease, coronary artery disease, and cerebrovascular disease (1-3). Abnormal metabolism and handling of homocysteine has been demonstrated after a methionine challenge in subjects with premature atherosclerosis, most of whom were heterozygous for cystathionine $\beta$-synthase (CBS) deficiency (1). Importantly, hyperhomocyst(e)inemia may be a modifiable risk factor for atherosclerosis, as plasma homocyst(e)ine levels may be lowered by dietary supplementation with folate and pyridoxine $(2,4)$.
The mechanisms by which hyperhomocyst(e)inemia creates a milieu that favors the development and progression of vascular disease have not been fully elucidated. Homocysteine influences multiple vascular responses, including coagulation, platelet function, vascular smooth muscle responses, and endothelial function. Endothelial injury and dysfunction remains one of the leading mechanisms contributing to the predisposition to the development of atherothrombotic vascular disease in hyperhomocyst(e)inemia. Acute infusion of homocysteine has been shown to induce frank endothelial cell damage in primates (5). Homocysteine has also been shown to alter the production and/or bioactivity of vasoregulatory mediators, including nitric oxide, by cultured endothelial cells $(6,7)$. Furthermore, homocysteine has been shown to impair endothelium-dependent vasodilation and regulation of blood flow (8), an effect that may play an important 
role in the pathogenesis of ischemic events in hyperhomocyst(e)inemia (9). Similar to the adverse effects described with severe elevations of plasma homocyst(e)ine, mild hyperhomocyst(e)inemia has been shown to be associated with impairment in endothelial function and vasoregulatory mechanisms in primates and human subjects (10-13).

The leading mechanism suggested for the adverse vascular effects of homocysteine on endothelial function involves oxidant stress with a depletion of bioactive nitric oxide (14). Homocysteine, like other thiolcontaining amino acids, undergoes auto-oxidation with the generation of reactive oxygen species (15). Reactive oxygen species such as superoxide anion may interact with nitric oxide to form peroxynitrite, leading to a depletion of biologically active nitric oxide (16). Previous investigations have also supported a role for hydrogen peroxide (and hydroxyl radical) in homocysteine-induced endothelial toxicity, as catalase was found to modulate endothelial injury by homocysteine (17). More recently, the importance of superoxide formation was underscored by the attenuation of homocysteine-induced endothelial dysfunction by superoxide dismutase (9). Furthermore, the antioxidant ascorbic acid has been shown to attenuate impairment in endothelium-dependent vasodilator function after a methionine challenge in human subjects (18).

A model of mild hyperhomocyst(e)inemia due to heterozygous deficiency of CBS was developed by targeted gene disruption in mice by Watanabe and colleagues (19). This model is very useful for assessing the specific adverse vascular effects of homocyst(e)ine; human studies suffer from the confounding effects of other risk factors and frank atherosclerosis (11-13), and vitamin-deficient diet studies in primates may be accompanied by other effects of vitamin deficiency states that modulate vascular function (10). In the present study, we sought to test the effects of mild hyperhomocyst(e)inemia on vascular function. Specifically, we examined the effect of mild hyperhomocyst(e)inemia on endothelium-dependent and -independent vasodilator function. In addition, we measured markers of oxidant stress to attempt to provide support for the hypothesis that mild elevations in homocyst(e)ine impart an oxidant load that contributes to its adverse effect on the vascular endothelium by decreasing bioactive nitric oxide availability.

\section{Methods}

Materials and animals. Acetylcholine, methacholine, bradykinin, A23187, and sodium nitroprusside were obtained from Sigma Chemical Co. (St. Louis, Missouri, USA). Mice heterozygous for disruption in the CBS gene were kindly provided by N. Maeda at the University of North Carolina (Chapel Hill, North Carolina, USA) and subsequently bred at our institution. CBS was inactivated using homologous recombination in mouse embryonic stem cells to disrupt the coding sequence of the CBS gene, as described previously (19). Heterozygous (-/+) CBS-deficient mice and littermate, wild type $(+/+)$ control mice were used at 10-20 weeks of age for the experiments assessing vascular function. The animals were fed standard chow and handled following NIH guidelines. The procedures were approved by the Institutional Animal Care and Use Committee at Boston University Medical Center.

Genotype determination. Tail biopsies were obtained from mice at 3-4 weeks of age and were homogenized using $1 \mathrm{mg} / \mathrm{mL}$ proteinase $\mathrm{K}, 1.0 \% \mathrm{SDS}$, and a buffer containing $0.1 \mathrm{~mol} / \mathrm{L}$ EDTA ( $\mathrm{pH} 8.0), 0.05 \mathrm{~mol} / \mathrm{L}$ Tris (pH 8.5), and $0.2 \mathrm{~mol} / \mathrm{L} \mathrm{NaCl}$. DNA was extracted with phenol/chloroform/isoamyl alcohol, precipitated and rinsed with ethanol, and amplified by PCR for sequences in intron 3 and the Neo insert in $\mathrm{CBS}^{-/+}$mice (19). The product was run on a $1 \%$ agarose gel, and $\mathrm{CBS}^{-/+}$mice are identified by two bands with differing electrophoretic mobility.

Phenotype determination: homocysteine level and CBS activity. Blood was obtained from the mice at the time of sacrifice and collected in tubes containing EDTA or citrate. Plasma was obtained by centrifugation and stored at $-80^{\circ} \mathrm{C}$. Total plasma homocyst(e)ine was measured by an HPLC method with electrochemical detection using a commercially available kit (Bioanalytical Systems, Inc., West Lafayette, Indiana, USA). Liver was harvested from mice at the time of sacrifice, snap frozen, and stored at $-80^{\circ} \mathrm{C}$. CBS activity was measured from crude liver extracts by the method of Kashiwamata and Greenberg (20). The assay is based on a shift in the absorption spectrum of the ninhydrin reagent upon reacting with cystathionine generated from its precursors by cystathionine $\beta$-synthase. Enzyme activity was expressed as units (micromoles of cystathionine formed per hour) per milligram of protein.

Vascular ring preparation. Vascular relaxation in isolated aortic rings was measured using an isometric myograph. Mice were anesthetized with ketamine and xylazine (40 and $8 \mathrm{mg} / \mathrm{kg}$, respectively), and the thoracic aortae were harvested and immediately placed on iced Krebs buffer of the following ionic composition: 188.3 $\mathrm{mM} \mathrm{NaCl}, 4.7 \mathrm{mM} \mathrm{KCl}, 2.5 \mathrm{mM} \mathrm{CaCl}_{2}, 1.2 \mathrm{mM} \mathrm{MgSO}_{4}$, $1.2 \mathrm{mM} \mathrm{KH}_{2} \mathrm{PO}_{4}, 25 \mathrm{mM} \mathrm{NaHCO}_{3}$, and $12 \mathrm{mM}$ glucose. The connective tissue of the adventitia was removed, and two 3-mm rings were cut contiguously from the proximal descending thoracic aorta. The rings were mounted in a Kent horizontal myograph with a force transducer (Kent Scientific Co., Litchfield, Connecticut, USA) to measure isometric tension. The rings were maintained in Krebs buffer at $37^{\circ} \mathrm{C}$ and aerated with $95 \% \mathrm{O}_{2}-5 \% \mathrm{CO}_{2}$. A total resting tension of $2.5-2.8 \mathrm{~g}$ was applied stepwise, and the ring was allowed to equilibrate for 60 minutes. Maximal contraction was determined with $10 \mu \mathrm{mol} / \mathrm{L}$ phenylephrine, after which the ring was washed with Krebs solution. Vessels were recontracted to approximately half-maximal contraction, typically requiring $0.1 \mu \mathrm{M}$ phenylephrine. After stabilization of contraction, relaxation was measured in response to cumulative addition of acetylcholine $\left(10^{-9}-10^{-5} \mathrm{M}\right)$ or sodium nitroprusside $\left(10^{-9}-10^{-5} \mathrm{M}\right)$. 
Mesenteric microcirculation studies. Vascular reactivity in the mesenteric circulation was assessed in vivo using videomicroscopy (21). Mice were anesthetized with ketamine and xylazine ( 40 and $8 \mathrm{mg} / \mathrm{kg}$, respectively) by intraperitoneal injection. Body temperature, monitored using a rectal probe, was maintained at $37^{\circ} \mathrm{C}$ with a heated platform of the videomicroscope apparatus and a heating lamp. A segment of small intestine was gently exteriorized through a small, midline abdominal incision. The omentum was draped over a cover slip on a support for videomicroscopy. The preparation was continuously superfused with $0.15 \mathrm{M} \mathrm{NaCl}$ (at $1 \mathrm{~mL} / \mathrm{min}$ ) heated to $37^{\circ} \mathrm{C}$. The mesenteric circulation was visualized through a Nikon Optip Hot-2 microscope (40× water immersion objective lens) and the image projected onto an HR-1000 monitor (DageMTI, Inc., Michigan City, Indiana, USA) using an Attofluor high-intensity camera (Atto Instruments Inc., Rockville, Maryland, USA). The final screen image was magnified 64,000×. A single mesenteric arteriole (measuring $20-30 \mu \mathrm{m}$ in diameter) was selected and used for measurements throughout each experiment. The inner luminal diameter of the mesenteric arteriole was measured using a videocaliper apparatus (Microcirculation Research Institute, Texas A\&M College of Medicine, College Station, Texas, USA). Vessel diameter was measured at baseline and in response to the addition of agonists to the superfusate after an equilibration period of 5 minutes. Concentration-response curves were determined to methacholine, bradykinin, A23187, and sodium nitroprusside $\left(10^{-7}-10^{-4} \mathrm{M}\right)$. Before each dose of agonist, the omentum was washed with saline and restoration of baseline vessel diameter confirmed. The response was expressed as percent change in vessel diameter compared with baseline. We also superfused the mesentery with $\mathrm{Cu} / \mathrm{Zn}$ superoxide dismutase at 150 $\mathrm{U} / \mathrm{mL}$ to evaluate the effect of this agent on endothelial dysfunction in response to $10^{-4} \mathrm{M}$ methacholine.

In separate studies, the hemodynamic effects of a superfusion of methacholine or sodium nitroprusside were determined. A catheter was placed in the internal carotid artery of an anesthetized animal, and the blood pressure was monitored using a COBE disposable pressure transducer (COBE Laboratories, Lakewood, Colorado, USA) and recorded on a Grass polygraph chart recorder (Grass Instruments, Quincy, Massachusetts, USA).

Cyclic guanosine monophosphate levels. Cyclic guanosine monophosphate (cGMP) content was measured in isolated thoracic aortae as described previously (22). The thoracic aortae were harvested from anesthetized mice and immediately placed in iced Krebs solution. The loose connective tissue of the adventitia was removed and the vessel carefully incised along its length to expose the endothelial surface. The vessel was placed in Krebs solution at $37^{\circ} \mathrm{C}$ and aerated with $95 \% \mathrm{O}_{2}-5 \% \mathrm{CO}_{2}$ for 30 minutes. The vessel was precontracted with $0.1 \mu \mathrm{M}$ phenylephrine prior to exposure to $1 \mu \mathrm{mol} / \mathrm{L}$ acetylcholine for 1 minute. The aorta was snap-frozen in liq- uid nitrogen and stored at $-80^{\circ} \mathrm{C}$. The tissue was homogenized with $6 \%$ ice-cold trichloroacetic acid and centrifuged at $2,000 \mathrm{~g}$ for 5 minutes at $4{ }^{\circ} \mathrm{C}$. The trichloroacetic acid precipitate was solubilized with $\mathrm{NaOH}$ and used for protein determination. Cyclic GMP content in the supernatant was measured using a commercially available immunoassay (Cayman Chemical Co., Ann Arbor, Michigan, USA) according to the manufacturer's instructions.

Tissue 8-isoprostane/phospholipid bydroperoxide content. Mice were sacrificed and plasma was obtained by centrifugation of blood collected in tubes containing EDTA. Tissue samples were harvested, snap frozen in liquid nitrogen, and stored at $-80^{\circ} \mathrm{C}$. Measurement of the isoprostane 8-epi-PGF ${ }_{2 \alpha}$ (8-IP) purified from plasma, liver, and aortic samples was made using a commercially available immunoassay (Cayman Chemical Co., Ann Arbor, Michigan, USA) according to the manufacturer's instructions. Measurement of phospholipid hydroperoxide levels in hepatic tissue was performed by HPLC using a LCSi column as described previously (23).

Aortic superoxide generation. Superoxide anion production was measured using lucigenin chemiluminescence (24). Aortas were removed from $\mathrm{CBS}^{-/+}$and $\mathrm{CBS}^{+/+}$mice and cleaned of adventitia. The vessels were then placed in a balanced salt solution containing glucose (BSSG; composition: $65 \mathrm{mM} \mathrm{NaCl} ; 2.5 \mathrm{mM} \mathrm{KCl} ; 0.25 \mathrm{mM} \mathrm{MgCl}_{2}$; $0.75 \mathrm{mM} \mathrm{CaCl}_{2} ; 10 \mathrm{mM} \mathrm{Na}$-HEPES; $22 \mathrm{mM} \mathrm{H}_{3} \mathrm{PO}_{4}$; and $10 \mathrm{mM}$ glucose [pH 7.4]), and were allowed to equilibrate for 45 minutes at $37^{\circ} \mathrm{C}$ under $5 \% \mathrm{CO}_{2}$. The vessels were then incubated for 15 minutes, in darkness, in a $5 \mu \mathrm{M}$ lucigenin/BSSG solution. Lucigenin chemiluminescence was measured in a darkroom using a Turner Designs TD20e luminometer during 15-second intervals 20 times over 5 minutes. Background chemiluminescence was then subtracted and measurements were standardized using a standard curve of superoxide production known from quantities of xanthine and xanthine oxidase. The vessels were dried for 24 hours under a heat lamp for determination of dry weight. Superoxide production was expressed as $\mu \mathrm{mol} \mathrm{O}_{2}^{-\bullet}$ per 5 minutes per milligram of dry weight of aortic tissue. As a confirmation of the data obtained with lucigenin, we performed studies using the cytochrome C assay (25).

Histological assessment. Tissue, including heart, aorta, and mesentery, was excised from $\mathrm{CBS}^{-/+}$and $\mathrm{CBS}^{+/+}$mice at approximately 10 weeks of age. The tissues were fixed in $4 \%$ formalin, embedded in paraffin, and sections stained with hematoxylin and eosin and Masson trichrome.

Immunohistochemistry for endothelial NO synthase and for 3-nitrotyrosine. Tissues were deparaffinized (xylene $2 \times$, toluene $1 \times, 100 \%$ ethanol $2 \times, 95 \%$ ethanol, $70 \%$ ethanol, deionized $\mathrm{H}_{2} \mathrm{O}$, and PBS [pH 7.4]) and incubated with $3 \% \mathrm{H}_{2} \mathrm{O}_{2}$ for 5 minutes. After washing with PBS, the tissue was incubated with a blocking solution of $8 \%$ BSA for 1 hour at room temperature. After washing with PBS, the slides were incubated with $10 \mu \mathrm{g} / \mathrm{mL}$ primary antibody to eNOS (Transduction Laboratories, Lexington, Kentucky, USA) overnight at $4^{\circ} \mathrm{C}$. After the 


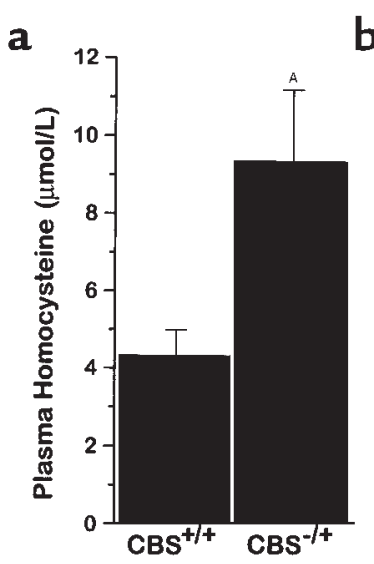

b

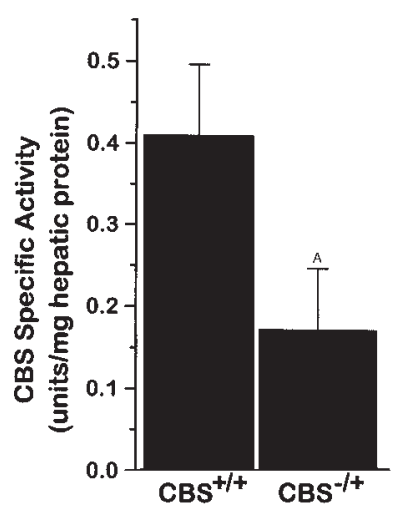

Figure 1

(a) Total plasma homocysteine concentration in $\mathrm{CBS}^{+/+}$mice $(n=5)$ and $\mathrm{CBS}^{-/+}$mice $(n=7)$, and (b) CBS activity from liver homogenates in $\mathrm{CBS}^{+/+}$mice $(n=6)$ and $\mathrm{CBS}^{-/+}$mice $(n=6) .{ }^{\mathrm{A}} \mathrm{P}<0.05$.

slides were washed (PBS), the secondary antibody (Vectastain kit with mouse biotinylated secondary antibody; Vector Laboratories, Burlingame, California, USA) was applied and incubated for 1 hour at room temperature. Tissue eNOS was visualized using the $\mathrm{DAB}$ substrate method as described in the Vector Laboratories DAB Substrate kit. The slides were mounted and sealed for microscopic visualization.

Peroxynitrite production was assessed by the presence of the stable end product of its interaction with cellular tyrosine residues, 3-nitrotyrosine, by immunostaining using an anti-3-nitrotyrosine antibody (Upstate Biotechnology, Lake Placid, New York, USA) according to the manufacturer's instructions (26-28). Tissue sections were deparaffinized, and endogenous peroxides were quenched by the addition of $3 \%$ hydrogen peroxide in PBS. Positive controls were incubated with $1 \mathrm{mM}$ exogenous peroxynitrite for 10 minutes. Sections were first incubated with $8 \%$ BSA (blocking agent) for 30 minutes, then with polyclonal rabbit $\alpha$-nitrotyrosine antibody (Upstate Biotechnology) at $4 \mu \mathrm{g} / \mathrm{mL}$ for 1 hour at room temperature, followed by a goat $\alpha$-antirabbit IgG antibody coupled to 3-3'-diaminobenzidine $(\mathrm{DAB})$ peroxidase (Vector Laboratories). The presence of nitrotyrosine was detected by DAB staining.
Data analysis. Continuous data were expressed as mean \pm SEM. Student's $t$ tests were used to compare differences between groups for continuous variables. Two-way ANOVA was used to examine differences in the dose response to agonists between groups, with post hoc analysis performed by the method of StudentNewman-Keuls. Statistical significance was defined as a $P$ value of less than 0.05 .

\section{Results}

Homocyst(e)ine concentrations and CBS activity. To characterize the $\mathrm{CBS}^{-/+}$mice and compare them to $\mathrm{CBS}^{+/+}$ mice, we measured plasma homocyst(e)ine concentration and hepatic CBS activity. We found more than a twofold increase in random plasma total homocysteine concentration in $\mathrm{CBS}^{-/+}$mice compared with $\mathrm{CBS}^{+/+}$ mice $(P<0.05)$ (Figure 1a). Commensurate with this difference, there was an approximately $50 \%$ reduction in CBS activity from crude liver extracts in the $\mathrm{CBS}^{-/+}$mice compared with $\mathrm{CBS}^{+/+}$mice $(P<0.05)$ (Figure $\left.1 \mathrm{~b}\right)$. These findings confirm the phenotypic expression of partial CBS deficiency and mild hyperhomocyst(e)inemia in mice with heterozygous disruption of the CBS gene.

Aortic relaxation. Acetylcholine and sodium nitroprusside each produced dose-dependent relaxation in precontracted aortic rings in both $\mathrm{CBS}^{-/+}$and $\mathrm{CBS}^{+/+}$mice. However, aortic relaxation to acetylcholine was attenuated in $\mathrm{CBS}^{-/+}$mice compared with $\mathrm{CBS}^{+/+}$mice (Figure 2a). The concentration of acetylcholine needed to induce half-maximal relaxation was $1 \times 10^{-6} \mathrm{M}$ in the $\mathrm{CBS}^{-/+}$mice compared with $2 \times 10^{-7} \mathrm{M}$ in the $\mathrm{CBS}^{+/+}$ mice $(P<0.001)$. Aortic relaxation to sodium nitroprusside was similar in the $\mathrm{CBS}^{-/+}$and $\mathrm{CBS}^{+/+}$mice (Figure $2 \mathrm{~b}$ ). This result demonstrates preservation of endothelium-independent relaxation to a nitric oxide donor in conductance vessels in $\mathrm{CBS}^{-/+}$mice.

Mesenteric vascular reactivity. Methacholine, bradykinin, and A23187 all produced dose-dependent vasodilation of mesenteric arterioles in $\mathrm{CBS}^{+/+}$mice: there was a maximal $9.1 \pm 1.1 \%$ increase in arteriolar diameter while superfusing methacholine at $10^{-5} \mathrm{M}$, $9.5 \pm 2.2 \%$ increase in diameter while superfusing bradykinin at $10^{-5}$ and $10^{-4} \mathrm{M}$ (Figure 3 , a and $\mathrm{b}$ ), and a $16.8 \pm 3.3 \%$ increase in diameter while superfusing

\section{Figure 2}

Relaxation of isolated, precontracted aortic rings in response to acetylcholine (a) and sodium nitroprusside (b) in $\mathrm{CBS}^{+/+}$mice (circles; $n=9)$ and $\mathrm{CBS}^{-/+}$ mice (squares; $n=9$ ). ${ }^{A} P<0.05 ;{ }^{B} P<0.001$ $C P=N S$.
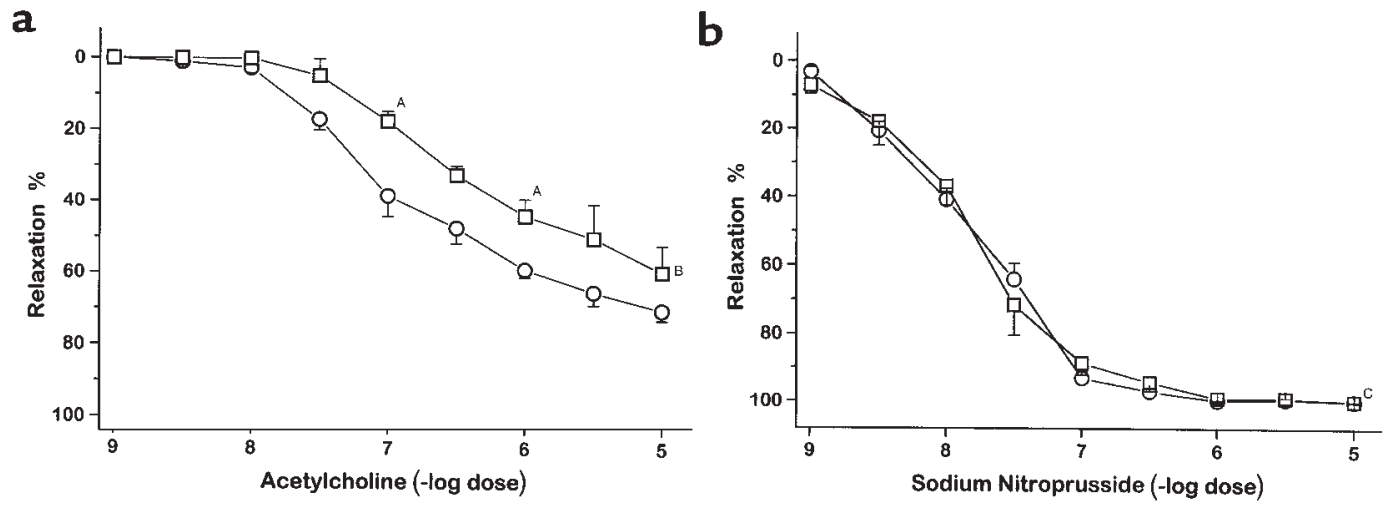
$10^{-6}$ M A23187 (data not shown). In contrast, mesenteric arterioles from $\mathrm{CBS}^{-/+}$mice underwent dosedependent vasoconstriction to methacholine, bradykinin, and A23187: there was a maximal $15.1 \pm 2.1 \%$ decrease in vessel diameter while superfusing methacholine at $10^{-5} \mathrm{M}$, a maximal $12.8 \pm 1.9 \%$ decrease in vessel diameter while superfusing bradykinin at $10^{-4}$ $\mathrm{M}$, and a maximal $13.4 \pm 2.3 \%$ decrease in vessel diameter while superfusing A23187 at $10^{-6} \mathrm{M}$, which were significantly different from the response of $\mathrm{CBS}^{+/+}$mice in each case $(P<0.001$ for methacholine, $P<0.05$ for bradykinin, and $P<0.01$ for A23187). This paradoxical vasoconstriction to these agents is indicative of impaired endothelium-dependent vasodilator responses in $\mathrm{CBS}^{-/+}$mice involving the microcirculation. Mesenteric arteriolar relaxation to sodium nitroprusside was similar in $\mathrm{CBS}^{-/+}$and $\mathrm{CBS}^{+/+}$mice (Figure 3c).

Studies using $150 \mathrm{U} / \mathrm{mL} \mathrm{Cu/Zn} \mathrm{superoxide} \mathrm{dismu-}$ tase superfused for 30 minutes over the mesentery of $\mathrm{CBS}^{-/+}$mice showed reversal of the vasoconstrictor response to $10^{-5} \mathrm{M}$ methacholine: $-11.0 \pm 2.6 \%$ vs. +11.3 $\pm 1.6 \%$ for animals treated without or with superoxide dismutase, respectively $(n=4-6 ; P<0.001)$. The addition of $\mathrm{Cu} / \mathrm{Zn}$ superoxide dismutase had no significant effect on the response to sodium nitroprusside in wildtype mice. These data support the view that the abnormal endothelium-dependent vascular response is a consequence, in part, of enhanced reactive oxygen species generation.

Blood pressure was monitored via carotid artery cannulation during mesenteric superfusion of both methacholine and sodium nitroprusside at maximal concentrations $\left(10^{-5} \mathrm{M}\right)$ in two wild-type and three $\mathrm{CBS}^{-/+}$mice. Blood pressure remained constant while superfusing both vasodilators, confirming a lack of systemic effects of these vasodilators during this experimental protocol (data not shown).

Cyclic GMP levels. The aorta from $\mathrm{CBS}^{-/+}$mice had approximately $43 \%$ lower cGMP levels after stimulation with acetylcholine for 1 minute compared with $\mathrm{CBS}^{+/+}$ mice (Figure 4). This result is consistent with impaired nitric oxide bioactivity in these mildly hyperhomocyst(e)inemic mice.

8-Isoprostane and phospholipid hydroperoxide level. Serum levels of 8-IP were $17 \%$ higher in $\mathrm{CBS}^{-/+}$mice than in $\mathrm{CBS}^{+/+}$mice, with a trend toward significance (Figure 5). There was no significant difference in the hepatic levels of 8 -IP $(0.83 \pm 0.19$ vs. $0.7 \pm 0.14 \mathrm{pg} / \mathrm{mg}$ protein $)$ or phospholipid hydroperoxides $(326.4 \pm 31.5$ vs. $372.3 \pm 32.4$ $\mathrm{AU} / \mathrm{mg}$ protein) between the $\mathrm{CBS}^{-/+}$and $\mathrm{CBS}^{+/+}$mice.

Aortic superoxide generation. Aortas were rapidly removed from $\mathrm{CBS}^{-/+}$and $\mathrm{CBS}^{+/+}$mice, cleaned of adventitia, and analyzed for superoxide anion generation using the lucigenin assay. Aortic tissue from $\mathrm{CBS}^{-/+}$mice generated 7.4-fold more superoxide anion than that from $\mathrm{CBS}^{+/+}$mice $(35.7 \pm 6.7$ vs. $4.8 \pm 3.5$ $\mu \mathrm{mol}$ superoxide $/ 5 \mathrm{~min} / \mathrm{g}$ dry weight, respectively; $P=$ 0.0153), consistent with the increase in oxidant stress in the setting of mild hyperhomocyst(e)inemia due to partial CBS deficiency. Confirming these results, the cytochrome $\mathrm{C}$ assay for superoxide generation showed that $\mathrm{CBS}^{-/+}$mice generated 4.1 -fold more superoxide than $\mathrm{did} \mathrm{CBS}^{+/+}$mice: $21.2 \pm 1.5$ vs. $5.1 \pm 1.0 \mu \mathrm{mol}$ superoxide $/ 5 \mathrm{~min} / \mathrm{g}$ dry weight, respectively $(n=3-4 ; P$ $<$ 0.001). Importantly, $\mathrm{Cu} / \mathrm{Zn} \mathrm{SOD}$ at $150 \mathrm{U} / \mathrm{ml}$ reduced this signal by $54 \%$.

Histologic assessment and 3-nitrotyrosine immunostaining. There were no appreciable differences in aortic and mesenteric arteriolar morphology by hematoxylin and eosin and by Masson trichrome staining in the $\mathrm{CBS}^{-/+}$ mice compared with $\mathrm{CBS}^{+/+}$mice (Figure 6). Immunos-

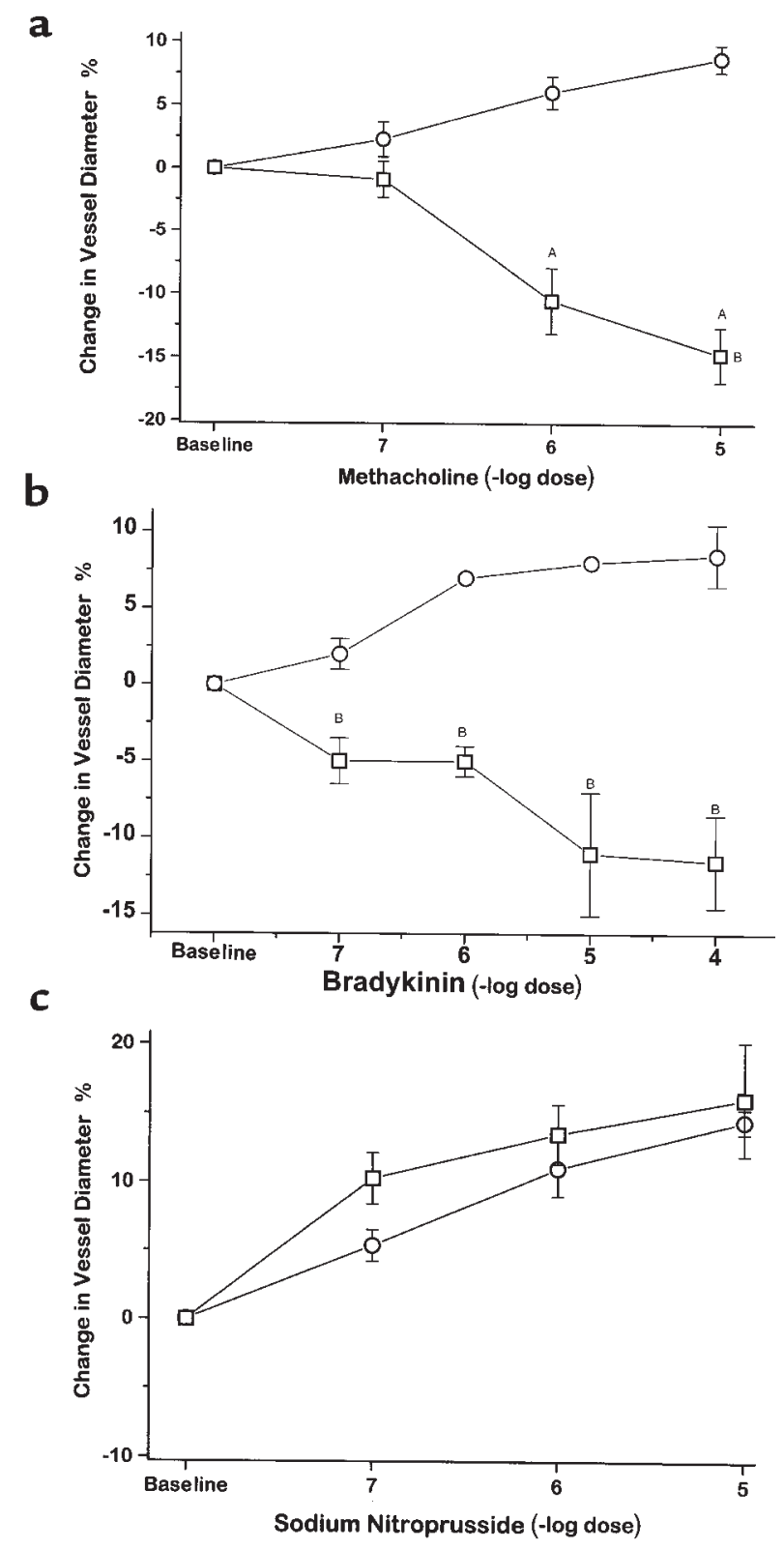

Figure 3

Mesenteric microvascular response to superfusion of methacholine (a), bradykinin (b), and sodium nitroprusside (c) in $\mathrm{CBS}^{+/+}$ mice (circles) $(n=4)$ and $\mathrm{CBS}^{-/+}$mice (squares) $(n=4)$. ${ }^{\mathrm{A}} P<0.05$; ${ }^{\mathrm{B}} P<0.001 ;{ }^{C} P=$ NS. 


\section{Figure 4}

Aortic cyclic GMP accumulation stimulated with acetylcholine for 1 minute in $\mathrm{CBS}^{+/+}$ mice $(n=4)$ and $\mathrm{CBS}^{-/+}$mice $(n=4) .{ }^{A} P=0.15$.

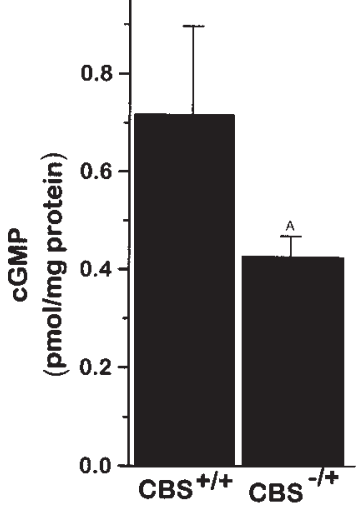

taining of aortic tissue with an anti-3-nitrotyrosine antibody showed greater staining for 3-nitrotyrosine in $\mathrm{CBS}^{-/+}$mice compared with $\mathrm{CBS}^{+/+}$mice (Figure 7). This increase in staining was largely confined to the endothelial surface, thus supporting increased peroxynitrite formation at this site. Immunostaining of aortic tissue with an anti-eNOS antibody showed similar staining of the endovascular surface in the $\mathrm{CBS}^{-/+}$mice compared with $\mathrm{CBS}^{+/+}$mice (Figure 8).

\section{Discussion}

The major finding of this study is that chronic, mild hyperhomocyst(e)inemia due to heterozygous cystathionine $\beta$-synthase deficiency leads to endothelial dysfunction. Mild hyperhomocyst(e)inemia impairs endothelium-dependent vasodilator function, in part due to diminished nitric oxide bioactivity, in both conductance and resistance vessels. This impairment in endothelial function was observed with evidence suggesting that increased oxidative stress may contribute to a depletion of bioactive nitric oxide.

Endothelial dysfunction with severe hyperhomocyst(e)inemia has been demonstrated in animal models and humans. Perfusion of homocysteine $(200 \mu \mathrm{M}$ and $2 \mathrm{mM}$ ) attenuated the increase in blood flow induced by acetylcholine, but not by adenosine, in the isolated pancreatic vascular bed (8). Superfusion of homocysteine $(1 \mathrm{mM})$ on the cerebral cortex impaired cerebrovascular vasodilatory responses induced by acetylcholine and hypercapnia, but not by papaverine (9). These studies, however, used concentrations of

\section{Figure 5}

Plasma 8-isoprostane levels from $\mathrm{CBS}^{+/+}$mice $(n=4)$ and $\mathrm{CBS}^{-/+}$mice $(n=10) .{ }^{A} P=0.07$. homocysteine far higher than typically encountered in the clinical setting, more closely resembling those observed in homocystinuria, a rare disorder caused by homozygous CBS deficiency. Humans with homocystinuria have impaired flow-mediated, endotheliumdependent vasodilation (29).

These findings have recently been extended to mildto-moderate-hyperhomocyst(e)inemic states, which are also associated with endothelial dysfunction. Monkeys with diet-induced mild hyperhomocyst(e)inemia exhibit diminished augmentation in hind-limb blood flow and impaired relaxation of carotid artery rings to acetylcholine (10). These vascular effects were observed with plasma homocyst(e)ine concentrations in the range of those encountered clinically in atherosclerosis. In humans, hyperhomocyst(e)inemia after a methionine challenge is associated with impairment in endothelium-dependent vasodilator function (11). There remains uncertainty, however, as to whether or not the vascular dysfunction in these models is caused by hyperhomocyst(e)inemia per se or other abnormalities induced by the modified (methionine-rich, folaterestricted) diet or the methionine challenge. This murine model of hyperhomocyst(e)inemia induced by genetic manipulation of one of the critical enzymes involved in the metabolism of homocysteine is devoid of these confounding issues.

This study suggests that mild hyperhomocyst(e)inemia due to partial CBS deficiency directly leads to endothelial dysfunction. Hyperhomocyst(e)inemic mice have attenuated aortic relaxation to the endothelium-dependent agonist acetylcholine. This observation contrasts with findings in humans, as normal endothelium-dependent vasodilator function was observed in the obligate heterozygous CBS- deficient parents of homocystinurics (29); however, total plasma homocyst(e)ine concentrations were not reported for the heterozygous CBS-deficient subjects. Furthermore, mild hyperhomocyst(e)inemia in humans is also multifactorial, with environmental factors, vitamin deficiencies, and enzyme variants contributing to the observed plasma concentration. Humans with mild hyperhomocyst(e)inemia from these heterogeneous causes demonstrate impaired flow-mediated, endothelium-dependent vasodilation $(12,13)$.

Hyperhomocyst(e)inemic mice exhibit paradoxical vasoconstriction of the mesenteric microcirculation to methacholine, bradykinin, and A23187, which is a manifestation of endothelial dysfunction. Paradoxical vasoconstriction to cholinergic stimulation is well known to occur in atherosclerotic coronary arteries (30), and this response represents the loss of the vasodilator action of the endothelium with unopposed constriction of vascular smooth muscle. Hyperhomocyst(e)inemia in this model appears to have a more pronounced effect on endothelial function in the microcirculation than on conductance vessels, which may contribute to the dysregulation of blood flow. Disruption in microvascular endothelial function in hyperho- 
mocyst(e)inemia may impair the regulation of blood flow and compensatory mechanisms during ischemia, as well as predispose to thrombotic complications.

Endothelial dysfunction has been linked to the development and progression of atherosclerosis (31) and is an integral step in atherogenesis appearing early and progressing with disease severity. Hyperhomocyst(e)inemia has been shown to be associated with endothelial dysfunction; however, it is unclear if this dysfunction contributes to the development of atherosclerosis or is a consequence of atherosclerosis. This study reveals that endothelial dysfunction occurs with prolonged exposure to mild hyperhomocyst(e)inemia in the absence of frank atherosclerotic vascular lesions. This study supports the view that endothelial dysfunction in hyperhomocyst(e)inemia is a consequence of the elevated homocyst(e)ine levels rather than a consequence of atherosclerotic vascular disease. This study also suggests that mild elevation in plasma homocyst(e)ine concentrations may predispose to the development and progression of atherosclerosis; however, mild hyperhomocyst(e)inemia alone may not be a sufficient stimulus for its development.

The mechanisms involved in the pathogenesis of endothelial dysfunction by homocysteine are still being elucidated. It is unlikely that the effect of mild homocysteine on vascular function is a consequence of nonselective impairment of vascular smooth muscle relaxation, given the normal vascular response to direct nitrovasodilators. In contrast with hyperhomocyst(e)inemic monkeys (10), mice with mild hyperhomocyst(e)inemia demonstrate normal relaxation to the endothelium-independent vasodilator sodium nitroprusside. Although a normal response to sodium nitroprusside does not exclude decreased sensitivity to nitric oxide, it does suggest preservation of endothelium-independent vasodilation.

Nitric oxide has a key role in the endothelium-dependent response to acetylcholine (32). Chronic exposure to elevated levels of homocyst(e)ine may alter the bioactivity of nitric oxide. Prolonged exposure of cultured endothelial cells to homocysteine decreased the bioaction of nitric oxide without altering NOS activity or eNOS gene transcription, and it does so, in part, by suppressing expression of cellular peroxidase (GPx-1). This phenomenon likely explains our ability to detect endothelial dysfunction in the absence of homocysteine itself in short-term in vitro studies (33). Our results suggest that endothelium-dependent nitric oxide bioactivity is impaired in chronic, mild hyperhomocyst(e)inemia. One of the critical pathways involved in nitric oxide bioactivity is the cyclic GMP pathway. Cyclic GMP accumulation is diminished in vascular tissue from hyperhomocyst(e)inemic mice stimulated with acetylcholine. This observation supports the view that diminished nitric oxide bioactivity is, at least in part, responsible for the impairment in endothelium-dependent vasodilator function. Potential mechanisms contributing to the impairment of nitric oxide bioactivity by homocysteine

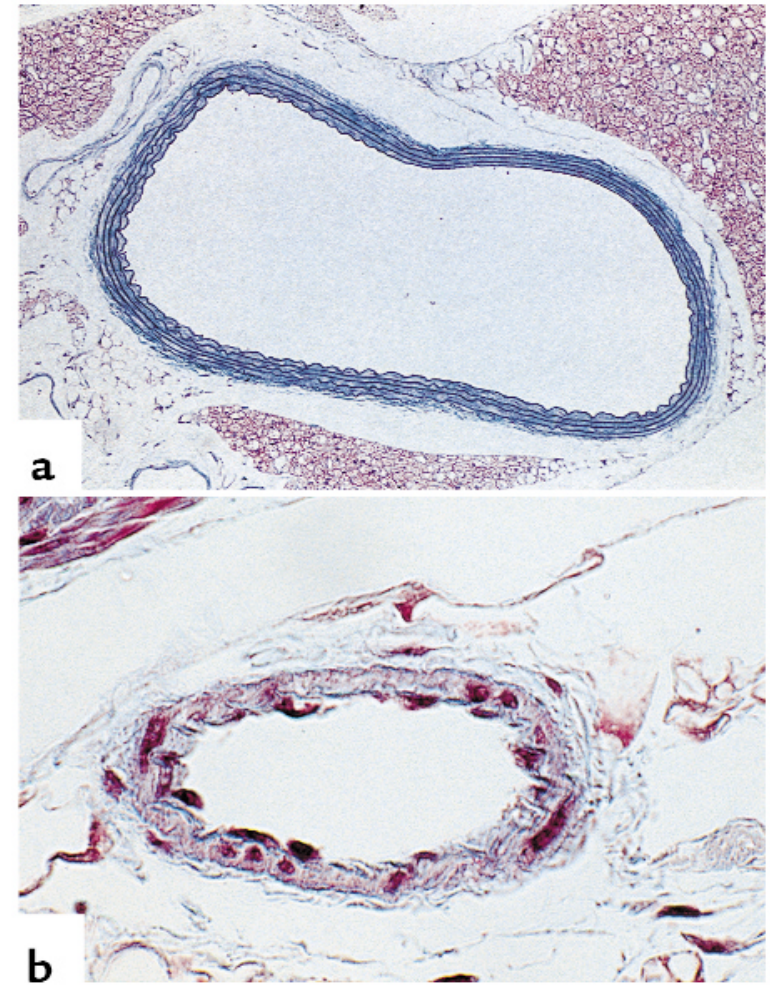

\section{Figure 6}

Cardiovascular histology of $\mathrm{CBS}^{-/+}$mouse (Masson trichrome staining). (a) Normal histological aspect of the aorta in a 10-week-old CBS mouse. (b) Cross section through an arteriole in the mesentery of a CBS mouse at 10 weeks of age. Original magnifications: (a) $\times 120,(\mathbf{b}) \times 200$.

include decreased production, diminished sensitivity, or increased (oxidative) destruction.

Oxidant injury imparted by hyperhomocyst(e)inemia may contribute to impairment in nitric oxide action and endothelial function. Previous studies revealed an attenuation of homocysteine-induced endothelial toxicity by oxygen radical scavenger enzymes and antioxidants, suggesting excessive production of reactive oxygen species $(9,17,18)$. Here we show a significant increase in aortic superoxide production in $\mathrm{CBS}^{-/+}$mice compared with $\mathrm{CBS}^{+/+}$mice. Free-radical generation induces oxidant stress that leads to peroxidation of cellular lipids with the formation of phospholipid hydroperoxides and $\mathrm{F}_{2}$-isoprostanes. $\mathrm{F}_{2}$-Isoprostanes are formed by nonenzymatic, free-radical-catalyzed reactions with peroxidation of arachidonic acid (34). Morrow and colleagues found that $\mathrm{F}_{2}$-isoprostanes are a reliable marker of in vivo lipid peroxidation and may play a role in pathophysiology as a vasoconstrictor (35). There is, however, some evidence to support the fact that $\mathrm{F}_{2}$-isoprostanes $\left(\mathrm{iPF}_{2 \alpha}-\mathrm{III}\right)$ can form in a cyclooxygenase-dependent fashion. This observation was demonstrated in vitro by treating platelets with indomethacin and aspirin (36), and by selectively inhibiting cyclooxygenase- 2 in monocytes in cell culture (37). Studies conducted in vivo, however, have 


\section{Figure 7}

Aortic arch cross sections stained for 3-nitrotyrosine. (a) $\mathrm{CBS}^{+/+}$with primary antibody; (b) $\mathrm{CBS}^{+/+}$preincubated with peroxynitrite (positive control); (c) $\mathrm{CBS}^{-/+}$without primary antibody (negative control); (d) $\mathrm{CBS}^{-/+}$with primary antibody.
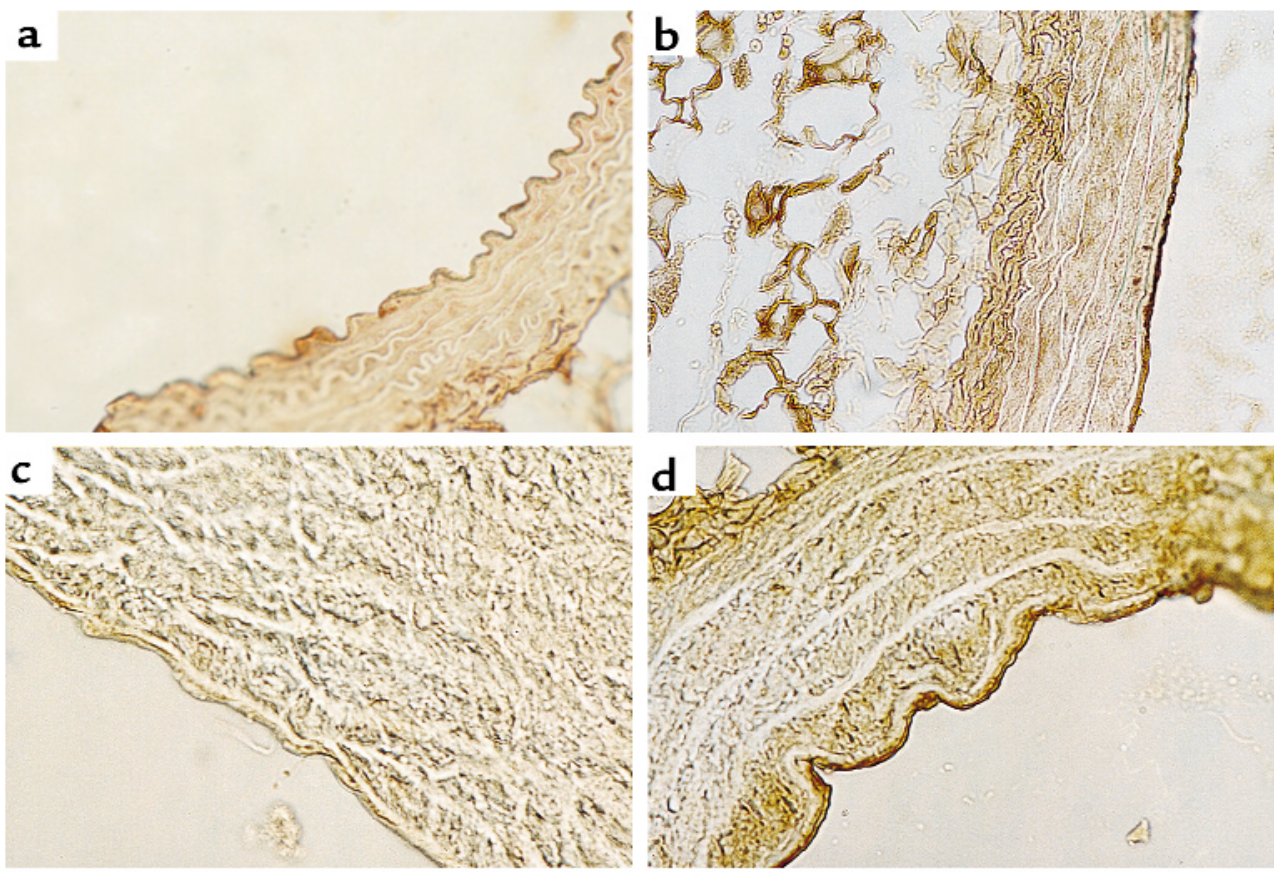

failed to confirm these findings. Urinary $\mathrm{iPF}_{2 \alpha}$-III excretion in diabetics (38) was unaffected by the administration of reversible and irreversible cyclooxygenase inhibitors, although urinary 11-dehydro- $\mathrm{TXB}_{2}$ (a thromboxane metabolite that depends on cyclooxygenase activity for its formation) excretion was decreased. Similar results have been observed using reversible and irreversible cyclooxygenase inhibitors in healthy volunteers (39) and using an irreversible cyclooxygenase inhibitor in cigarette smokers (40). We selected measurement of hepatic accumulation of phospholipid hydroperoxides and of serum and tissue accumulation of $\mathrm{F}_{2}$-isoprostanes as potential markers of oxidant burden. We found that although there was a trend toward an increase in serum 8-IP in $\mathrm{CBS}^{-/+}$compared with $\mathrm{CBS}^{+/+}$mice, neither hepatic 8-IP nor hepatic phospholipid hydroperoxides were elevated in $\mathrm{CBS}^{-/+}$mice. Superoxide-dependent lipid peroxidation may also pro- ceed through the formation of peroxynitrite, which may react with cellular tyrosine residues to form nitrosated end products. Immunostaining for one such end-product, 3-nitrotyrosine, was positive in aortic tissue from $\mathrm{CBS}^{-/+}$mice compared with $\mathrm{CBS}^{+/+}$mice, suggesting that oxidative stress and nitrosative stress are increased in mild hyperhomocyst(e)inemia. Thus, our findings support an increased oxidant load in chronic, mild hyperhomocyst(e)inemia that may alter nitric oxide metabolism.

In conclusion, this study demonstrates that a twofold elevation in plasma homocyst(e)ine due to heterozygous CBS deficiency impairs endothelium-dependent vasodilation of conductance and resistance vessels. Endothelial dysfunction was observed in the absence of frank atherosclerotic lesions, but in the presence of increased superoxide production and greater immunostaining for 3-nitrotyrosine, a marker of oxida-
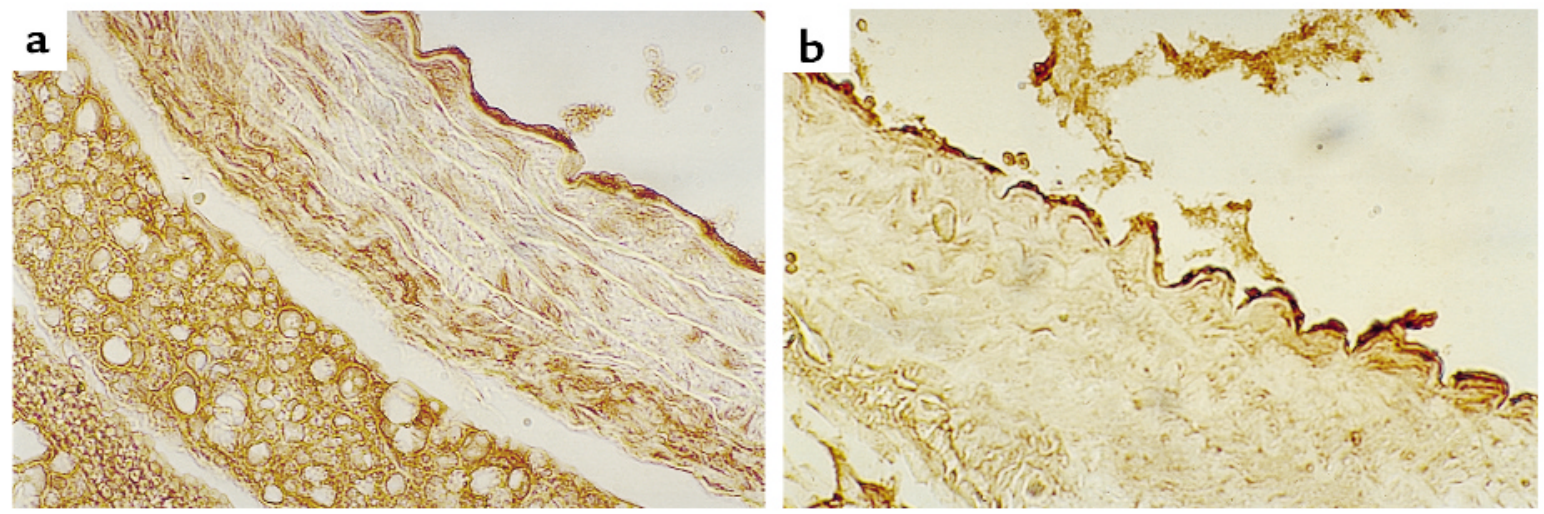

Figure 8

Aortic arch cross sections stained for eNOS in (a) $\mathrm{CBS}^{+/+}$and (b) $\mathrm{CBS}^{-/+}$mice. 
tive and nitrosative stress. We, therefore, conclude that increased oxidant stress imparted by chronic, mild hyperhomocyst(e)inemia likely contributes to endothelial dysfunction by depleting bioactive nitric oxide.

\section{Acknowledgments}

We thank S. Tribuna for her assistance in the preparation of this manuscript, and A. Ward Scribner for her technical assistance. This work was supported in part from NIH grants HL 48743, HL 53919, HL 58796, HL 55993, and HL 61795. R.T. Eberhardt was supported by an NIH Cardiovascular Training Grant and the CardioFellows Foundation provided by an unrestricted educational grant from Parke-Davis, Division of Warner-Lambert Company.

1. Clarke, R., et al. 1991. Hyperhomocysteinemia: an independent risk factor for vascular disease. N. Engl. J. Med. 324:1149-1155.

2. Stampfer, M.J., et al. 1992. A prospective study of plasma homocyst(e)ine and risk of myocardial infarction in US physicians. JAMA. 268:877-881.

3. Boers, G.H., Smals, A.G., Trijbels, F.J., Fowler, B., and Bakkeren, J.A. 1985. Heterozygosity for homocystinuria in premature peripheral and cerebral occlusive arterial disease. N. Engl. J. Med. 313:709-715.

4. Selhub, J., et al. 1995. Association between plasma homocysteine concentrations and extracranial carotid-artery stenosis. N. Engl. J. Med. 332:286-291

5. Harker, L.A., Harlan, J.M., and Ross, R. 1983. Effect of sulfinpyrazone on homocysteine-induced endothelial injury and arteriosclerosis in baboons. Circ. Res. 53:731-739.

6. Upchurch, G.R., Jr., et al. 1997. Stimulation of endothelial nitric oxide production by homocyst(e)ine. Atherosclerosis. 132:177-185.

7. Stamler, J.S., et al. 1993. Adverse vascular effects of homocysteine are modulated by endothelium-derived relaxing factor and related oxides of nitrogen. J. Clin. Invest. 91:308-318.

8. Quéré, I., et al. 1997. Effects of homocysteine on acetylcholine- and adenosine-induced vasodilation of pancreatic vascular bed in rats. $\mathrm{Br}$ J. Pharmacol. 122:351-357.

9. Zhang, F., Slungaard, A., Vercellotti, G.M., Iadecola, C. 1998. Superoxide-dependent cerebrovascular effects of homocysteine. Am. J. Physiol. 274:R1704-R1711.

10. Lentz, S.R., et al. 1996. Vascular dysfunction in monkeys with dietinduced hyperhomocyst(e)inemia. J. Clin. Invest. 98:24-29.

11. Bellamy, M.F., et al. 1998. Hyperhomocysteinemia after an oral methionine load acutely impairs endothelial function in healthy adults. Circulation. 98:1848-1852.

12. Woo, K.S., et al. 1997. Hyperhomocyst(e)inemia is a risk factor for arterial endothelial dysfunction in humans. Circulation. 96:2542-2544.

13. Tawakol, A., Omland, T., Gerhard, M., Wu, J.T., and Creager, M.A. 1997. Hyperhomocyst(e)inemia is associated with impaired endothelium-dependent vasodilation in humans. Circulation. 95:1119-1121.

14. Loscalzo, J. 1996. The oxidant stress of hyperhomocyst(e)inemia. J. Clin. Invest. 98:5-7.

15. Heinecke, J.W., Rosen, H., Suzuki, L.A., and Chait, A. 1987. The role of sulfur-containing amino acids in superoxide production and modification of low density lipoprotein by arterial smooth muscle cells. $J$. Biol. Chem. 262:10098-10103.

16. Gryglewski, R.J., Palmer, R.M., and Moncada, S. 1986. Superoxide anion is involved in the breakdown of endothelium-derived vascular relaxing factor. Nature. 320:454-456.

17. Starkebaum, G., and Harlan, J.M. 1986. Endothelial cell injury due to copper-catalyzed hydrogen peroxide generation from homocysteine. J. Clin. Invest. 77:1370-1376.

18. Chambers, J.C., McGregor, A., Jean-Marie, J., Obeid, O.A., and Kooner, J.S. 1999. Demonstration of rapid onset vascular endothelial dys- function after hyperhomocysteinemia: an effect reversible with vitamin C therapy. Circulation. 99:1156-1160.

19. Watanabe, M., et al. 1995. Mice deficient in cystathionine $\beta$-synthase: animal models for mild and severe homocyst(e)inemia. Proc. Natl. Acad. Sci. USA. 92:1585-1589.

20. Kashiwamata, S., and Greenberg, D.M. 1970. Studies of cystathionine synthase of rat liver. Properties of the highly purified enzyme. Biochim. Biophys. Acta. 212:488-500.

21. Suzuki, H., Zweifach, B.W., Schmid-Schonbein, G.W. 1995. Vasodilator response of mesenteric arterioles to histamine in spontaneously hypertensive rats. Hypertension. 26:397-400.

22. Bossaller, C., et al. 1987. Impaired muscarinic endothelium-dependent relaxation and cyclic guanosine $5^{\prime}$-monophosphate formation in atherosclerotic human coronary artery and rabbit aorta. J. Clin. Invest. 79:170-174.

23. Shwaery, G., Samii, J., Frei, B., and Keaney, J.F., Jr. 1998. Determination of phospholipid oxidation in cultured cells. Methods Enzymol. 300:51-57.

24. Skatchkov, M.P., et al. 1999. Validation of lucigenin as a chemiluminescent probe to monitor vascular superoxide as well as basal vascular nitric oxide production. Biochem. Biophys. Res. Commun. 254:319-324.

25. Lang, D., Mosfer, S.I., Shakesby, A., Donaldson, F., and Lewis, M.J. 2000. Coronary microvascular endothelial cell redox state in left ventricular hypertrophy. The role of angiotensin II. Circ. Res. 86:463-469.

26. Beckman, J.S., Beckman, T.W., Chen, J., Marshall, P.A., and Freeman, B.A. 1990. Apparent hydroxyl radical production by peroxynitrite: implications for endothelial injury from nitric oxide and superoxide. Proc. Natl. Acad. Sci. USA. 87:1620-1624.

27. Haddad, I.Y., et al. 1994. Quantitation of nitrotyrosine levels in lung sections of patients and animals with acute lung injury. J. Clin. Invest. 94:2407-2413

28. Hammerman, S.I., Klings, E.S., Hendra, K.P., Upchurch, G.R., Jr., and Rishikof, D.C. 1999. Endothelial cell nitric oxide production in the acute chest syndrome. Am. J. Physiol. 277:H1579-H1592.

29. Celermajer, D.S., et al. 1993. Impaired endothelial function occurs in the systemic arteries of children with homozygous homocystinuria but not their heterozygous parents. J. Am. Coll. Cardiol. 22:854-858.

30. Ludmer, P.L., et al. 1986. Paradoxical vasoconstriction induced by acetylcholine in atherosclerotic coronary arteries. N. Engl. J. Med. 315:1046-1051

31. McLenachan, J.M., Williams, J.K., Fish, R.D., Ganz, P., and Selwyn, A.P. 1991. Loss of flow-mediated endothelium-dependent dilation occurs early in the development of atherosclerosis. Circulation. 84:1273-1278.

32. Palmer, R.M., Ferrige, A.G., and Moncada, S. 1987. Nitric oxide release accounts for the biological activity of endothelium-derived relaxing factor. Nature. 327:524-526.

33. Upchurch, G.R., Jr., et al. 1997. Homocyst(e)ine decreases bioavailable nitric oxide by a mechanism involving glutathione peroxidase. J. Biol. Chem. 272:17012-17017.

34. Morrow, J.D., et al. 1990. A series of prostaglandin F2-like compounds are produced in vivo in humans by a non-cyclooxygenase, free radicalcatalyzed mechanism. Proc. Natl. Acad. Sci. USA. 87:9383-9387.

35. Morrow, J.D., et al. 1995. Increase in circulating products of lipid peroxidation (F2-isoprostanes) in smokers. Smoking as a cause of oxidative damage. N. Engl. J. Med. 332:1198-1203.

36. Pratico, D., Lawson, J.A., and Fitzgerald, G.A. 1995. Cyclooxygenasedependent formation of the isoprostane, 8-epi prostaglandin $\mathrm{F}_{2 \alpha} \mathrm{J}$. Biol. Chem. 270:9800-9808.

37. Pratico, D., and FitzGerald, G.A. 1996. Generation of 8epiprostaglandin $\mathrm{F}_{2 \alpha}$ by human monocytes. Discriminate production by reactive oxygen species and prostaglandin endoperoxides synthase2. J. Biol. Chem. 271:8919-8924.

38. Davi, G., et al. 1999. In vivo formation of 8-iso-prostaglandin $F_{2 \alpha}$ and platelet activation in diabetes mellitus: effects of improved metabolic control and vitamin E supplementation. Circulation. 99:224-229.

39. Pratico, D., et al. 1998. $\operatorname{IPF}_{2 \alpha-1}$ : an index of lipid peroxidation in humans. Proc. Natl. Acad. Sci. USA. 95:3449-3454.

40. Reilly, M., Delanty, N., Lawson, J.A., and FitzGerald, G.A. 1996. Modulation of oxidant stress in vivo in chronic cigarette smokers. Circulation. 94:19-25. 